\title{
IDEOLOGI PATRIARKI DALAM FILM \\ (SEMIOTIKA JOHN FISKE PADA INTERAKSI AYAH DAN ANAK DALAM FILM CHEF)
}

\author{
Harry Setiawan ${ }^{1}$, Abdul Aziz $^{2}$, Debby Kurniadi ${ }^{3}$ \\ 1,2Program Studi IImu Komunikasi, Universitas Islam Riau \\ ${ }^{3}$ Program Studi IImu Komunikasi, STISIP Persada Bunda \\ harry.setiawan@comm.uir.ac.id ${ }^{1}$, abdulaziz@comm.uir.ac.id ${ }^{2}$, kurniadidebby@gmail.com ${ }^{3}$
}

\begin{abstract}
Abstrak
Film Chef yang beraliran drama - komedi ini dirilis pada tahun 2014 dengan menghasilkan US\$45 Juta pada dua minggu penayangannya di bioskop seluruh Amerika dan masuk jajaran film box office dengan rating 7,3/10 versi IMDb. Film ini menghadirkan banyak interaksi antara ayah dan anak yang bisa menjadi acuan bagi orang tua dalam membangun interaksi terhadap anak. Interaksi karakter Carl (Ayah) dan Percy (Anak) yang menjadi subjek penelitian ini diulas dengan pendekatan semiotika John Fiske. Hasil penelitian ini tersaji pada tiga level analisis semiotika John Fiske yaitu level realitas yang digambarkan dengan interaksi karakter Carl dan Percy di ruang-ruang sempit dan padat pada area food truck "El Jefe" maupun area lain baik interior (dalam ruang) maupun exterior (luar ruang). Level representasi yang digambarkan dengan sudut pengambilan gambar (angle) dan komposisi yang membawa penonton untuk tetap terlibat dalam setiap interaksi antar karakter. Terakhir level ideologi patriarki yang menjadi temuan dalam penelitian ini bahwa ideologi patriarki yang dihadirkan dalam film ini bisa dijadikan acuan dalam membangun interaksi ayah dan anak sehingga anak tersebut tidak kehilangan sosok orang tuanya.
\end{abstract}

Kata Kunci : interaksi sosial, patriarki, realitas, semiotika

\begin{abstract}
This drama-comedy film, Chef, was released in 2014 with the US $\$ 45$ million in two weeks of screenings in theaters across America and entered the ranks of box office films with a rating of $7.3 / 10$ of the IMDb version. This film presents many interactions between father and son that can be a reference for parents in building interactions with their children. The interaction of Carl (Father) and Percy (Son) characters are the subjects of this study are reviewed by John Fiske's semiotic approach. The results of this study presented at three levels of John Fiske's semiotic analysis; the level of reality depicted by Carl and Percy's character interaction in narrow and dense spaces in the "El Jefe" food truck area and other areas both interior (inside) and exterior (outside room). The level of representation depicted by the camera angle and the composition that brings the audience to remain involved in every interaction between characters. Finally, the level of patriarchal ideology found in this study that the patriarchal ideology presented in this film can use as a reference in building the interaction of fathers and children so that the child does not lose the figure of his parents.
\end{abstract}

Keywords:patriarchy, reality, semiotics, social interaction 


\section{PENDAHULUAN}

Film merupakan media komunikasi dalam ranah komunikasi massa. Film menjadi pengantar pesan yang signifikan dalam fenomena komunikasi dimana komunikasi merupakan alat tukar paling rumit dalam aktifitas makhluk hidup. Rumit, karena komunikasi mampu berada pada cabang apapun kehidupan makhluk di bumi. Rumit, karena keberhasilan komunikasi bergantung pada kemampuan berfikir logis (penalaran) dan logika berfikir (induktif - deduktif) sehingga kedua hal ini yang mendasari sesuatu menjadi ilmu pengetahuan dalam bingkai filosofis (Suriasumantri, 2017).

Pemahaman penonton dalam menterjemahkan makna tersembunyi dalam film menjadi sebuah suguhan yang menarik perhatian karen film mampu hadir dalam perspektif disiplin ilmu apapun sehingga dalam aspek bidang filosofis lainnya, film pun menjadi sesuatu yang rumit karena fenomena komunikasi dalam sebuah film mampu hadir ditengah batasan disiplin ilmu yang sudah tidak terlalu tegas dimana konvergensi masing-masing disiplin ilmu rutin terjadi yang membuat interaksi tokoh, setting lokasi, dialog, dan adegan dalam film yang keseluruhannya merupakan tindakan bisa terjadi dengan komunikasi menjadi medianya (Mulyana, 2018).

Selanjutnya, film mampu menciptakan sensasi, persepsi, atensi melibatkan banyak atau sedikit manusia sehingga yang selanjutnya fenomena komunikasi dalam film dapat berlangsung dalam diri manusia sebagai individu, kelompok, organisasi, maupun massa. Film diartikan dalam banyak tulisan merupakan potongan adegan yang saling berhubungan dalam menciptakan sebuah alur cerita (Dezheng, 2012; Fiske, 1985; Nurul \& Nugroho, 2017). Film merupakan salah satu media dalam komunikasi massa yang ditelisik dalam penelitian ini merupakan "cipratan" pesan hadir dalam narasi dan sensasi visualisasinya.

Chef, merupakan film yang menarik perhatian penulis untuk menelisik film ini lebih jauh. Chef merupakan film yang berhasil membukukan laba US\$ 45juta dengan skor 7,3/10 pada IMDb dan masuk dalam jajaran film box office selama 2 minggu penayanganya di bioskop. Film ini beraliran drama-komedi yang menggambarkan interaksi seorang chef professional "Carl Casper" yang diperankan oleh Jon Favreau yang sekaligus merangkap sebagai penulis cerita dan sutradara. Film ini menarik untuk diteliti karena dalam penceritaannya, film ini menggunakan alur linier dan tidak menghadirkan dinamika plot alur yang sulit untuk dipahami oleh penonton. Dalam plot ceritanya tidak banyak tokoh yang terlibat dalam kehidupan Carl Casper yang merupakan chef pada salah satu restoran terbaik di Los Angeles dan mengalami banyak intimidasi oleh pemilik restoran dalam berkreasi menyiapkan menu-menu restoran tersebut.

Casper selanjutnya diceritakan sebagai seorang ayah dari anak usia 10 tahun yang bernama Percy yang diperankan oleh Emjay Anthony hasil pernikahannya dengan wanita karir bernama Inez yang diperankan oleh Sofia Vergara yang diceritakan sudah bercerai namun tetap berhubungan baik demi Percy. Dalam kesehariaannya Casper ditemani oleh sahabat setianya bernama Martin, diperankan oleh John Leguizamo yang rela meninggalkan promosi jabatannya sebagai asisten chef sepeninggal Casper dari 
restoran tersebut akibat dipecat dan setia ikut membantu Casper memulai bisnis food truck "El Jefe."

Film ini menggabungkan realitas sosial masyarakat Los Angeles yang sibuk dan selalu dalam intimidasi serta realitas penggunaan media sosial (twitter) yang saat itu sedang merebak dan banyak digunakan warga LA. Yang menarik perhatian peneliti, bahwa pesan yang dihadirkan lebih besar dari sekedar visual dari kekuatan media sosial (twitter) dalam menyebarkan pesan dimana hal tersebut yang menjadi kajian dalam penelitian (Nico, 2016; Wulandari P.W, 2016) yang menggunakan pendekatan semiotika Pierce dan Fiske. Penelitian (Wulandari P.W, 2016) memfokuskan arah penelitiannya pada representasi media baru (twitter) dalam membangun reputasi food truck "El Jefe" sementara (Nico, 2016) yang menggunakan semiotika Pierce dalam menganalisa pesan pemasaran menggunakan twitter yang dilakukan dalam film Chef. Berjarak dengan dua penelitian sebelumnya, penulis melihat kemiripan fokus penelitian pada film Chef yang dilakukan oleh (Fahrian, 2017) dimana twitter masih menjadi fokus utama dalam kajiannya yang diulas dengan semiotika Bartes dimana penelitian tersebut menggali tanda konotasi yang berkaitan dengan mitos.

Keseluruhan penelitian semiotika pada film Chef yang pernah dilakukan sebelumnya merujuk pada satu tema tunggal yaitu pemanfaatan media sosial (twitter) yang diulas dan analisa dengan beberapa pendekatan semiotika. Penulis menghadirkan sudut pandang baru yang menjadi kebaharuan dalam penelitian ini yaitu pesan lain yang lebih fokus pada interaksi karakter dalam film ini yang akan diungkap melalui pendekatan semiotika Fiske adalah bagaimana interaksi ayah dan anak korban perceraian memberikan sebuah media komunikasi interpersonal bagi anak.

Interaksi Casper dan Percy menjadi sebuah suguhan cerita yang menarik untuk ditelisik mendalam kerena "cipratan-cipratan" simbol dalam realitas interpersonal yang mereka hadapi menjadi sebuah rangkaian representasi sosial yang dialami manusia di kota-kota besar dengan masalah seputar pekerjaan, rumah tangga, perceraian, dan anak-anak korban perceraian (broken home). Selanjutnya, penulis mencoba menggali kesimpulan lain dari cerita dalam film ini apakah film ini mampu menjadi panasea (Mulyana, 2017) dan salah satu rujukan bagi orang tua baik ayah maupun ibu yang memutuskan berpisah /cerai dalam membangun interaksi dengan anak sebagai korban perceraian.

Sebagai sebuah cabang analisis isi pada media massa yang sering dilakukan, seperti penelitian yang dilakukan oleh (Erica, 2010) yang meneliti film Rules of Engagement produksi tahun 2000 yang menemukan konstruksi interaksi sosial pada elemen-elemen film. Film beraliran action heroic ini menarik perhatian Erica (2010) karena konstruksi interaksi sosial yang terjadi pada gambaran realitas film tersebut menghadirkan kerumitan repsentasi identitas diri dan dari sudut pandang orang lain dan bagaimana interaksi antar komunitas pemuda dalam film tersebut. Selanjutnya penelitian Aisyah dan Catur (Nurul \& Nugroho, 2017) yang membongkar idealisme Marxisme pada film Guru Bangsa Tjokroaminoto produksi tahun 2015. Film ini beraliran biografi dimana 
semiotika John Fiske digunakan sebagai alat analisis dalam membongkar pemikiran marxisme yang hadir dalam film tersebut.

Semiotika dalam penelitian ini merupakan salah satu bentuk dari analisis isi pada media yang dikemas dalam pendekatan interaksi antar simbol, tanda, dan makna yang ada pada seputar pesan yang disampaikan media. Roland Bartes (1968) pada awalnya berusaha melakukan eksplorasi bahwa ilmu semiotika yang hadir dalam dirinya sebenarnya adalah suatu ilmu yang mengabaikan dimensi budaya dan berkonsentrasi pada sifat dan organisasi dari sistem tanda (Fiske, 1985). Selanjutnya perkembangan semiotika modern hingga saat ini menjadi sebuah pergulatan interkasi tiga hal yaitu, manusia sebagai penafsir, objek / benda yang dituju dan tanda yang ia bawa (LittleJohn \& Foss, 2009; Setiawan, 2016, 2019). Semiotika erat dikaitkan dengan tiga tokoh besar yaitu Pierce, Saussure, dan Bartes (LittleJohn \& Foss, 2016) namun dinamika perkembangan ilmu pengetahuan sosial semiotika mampu hadir dalam realitas manusia baik dalam itu simulacra kepunyaan Baudrillard (Holmes, 2005) ataupun realitas simbolis dalam film hasil pemikiran Fiske (Fiske, 1985; Vera, 2014).

Penelitian ini menggunakan pendekatan semiotika film yang dalam kajiannya film terbentuk atas realitas-realitas yang digambarkan dalam karakteristik utama film yaitu audiovisual dan terdapat dua unsur dalam audiovisual yaitu naratif dan simenatografi (Vera, 2014). Naratif merupakan unsur awal dalam mengantarkan pesan dalam setiap penggalan adegan /scene yang dihadirkan dalam bentuk monolog, dialog, ambience sound, serta masih hal lain yang dapat mendukung penyampaian pesan komunikasinya. Sinematografi mengisi posisi teknis dalam penyampaian pesan dalam scene yaitu lokasi, pengambilan gambar (angle, camera movement), artisitik, dan temperatur warna (kelvin) yang menghadirkan karakter, emosi, dan atmosfir tertentu (Tseng, 2013) pada setiap frame yang diambil.

Selanjutnya, interaksi karakter dalam film menciptakan "cipratan" pesan yang memberikan sensasi, persepsi, dan atensi penonton dalam intepretasi makna "cipratan" pesan tersebut, Dezheng memaknai interkasi karakter dalam film merupakan sebuah semiotik sosial-fungsional (Dezheng, 2012). Film menciptakan interaksi antar tanda yang bukan sekedar menjadi representasi realitas pada masyarakat menurut Turner dalam (Sobur, 2003) namun film juga mampu menciptakan realitasnya sendiri dan pada akhirnya diterapkan dalam kehidupan bermasyarakat.

Realitas film yang serupa dengan novel dimana benturan antara fiksi dan nonfiksi tertuang penuh dalam setiap entitas cerita pada film. Seluruh makna dari entitas tersebut diciptakan dengan menggunakan simbol-simbol yang dihadirkan dalam setiap realitasnya. Merujuk presmis interaksi simbolis Spradley dimana makna yang hadir pada setiap tindakan manusia merupakan sesuatu yang diberikan oleh manusia lain, interaksi sosial seseorang dengan orang lain memberikan berbagai hal dalam maknya simbolisnya, dan selajutnya manusia memodifikasi makna tersebut melalui proses penafsiran yang digunakan dalam kaitannya dengan berbagai hal yang dihadapi orang tersebut (Spradley, 2007). 
Misalnya, interaksi film action yang dimunculkan dalam simbol-simbol kekerasan, baku hantam, baku tembak, ledakan, darah, intrik, dan kematian dimaknai oleh penonton sebagai sebuah suguhan realitas film yang menarik. Namun tidak semua simbol-simbol tersebut terdapat pada semua film action, modifikasi simbol sering kali dilakukan dengan menambahkan perspektif lain bisa berupa adegan sex, eksploitasi sensualitas, heroic realism yang sering dijadikan unsur propaganda. Realitas yang hadir dalam film tidak jarang mampu menghadirkan sebuah budaya baru dimana menurut Fiske (1985) dan Hartley (1982) budaya populer yang muncul sebagai sebuah realitas budaya baru tidak sertamerta dapat membawa dampak buruk bagi masyarakat. la membuktikan bahwa melalui Film dan Televisi dapat membentuk budaya baru yang baik bagi masyarakat dimana melalui tayangan-tayangan Film dan juga Televisi mampu menciptakan lingkungan sosial yang baru dan baik bagi masyarakat yang tentu saja dihadirkan melalui konten yang baik pula (Fiske, 1985; Heller, 1982).

Tabel 1. Semiotika John Fiske

[sumber : Hasanah \& Taefur, 2016; Vera, 2014]

\begin{tabular}{|c|l|l|l|}
\hline No & \multicolumn{1}{|c|}{ Level Analisis } & \multicolumn{1}{|c|}{ Domain Analisis } & \multicolumn{1}{|c|}{ Unsur Audiovisual } \\
\hline 1 & Level Realitas & $\begin{array}{l}\text { Penampilan, Kostum, Riasan, } \\
\text { Lingkungan, Perilaku, Cara Bicara, } \\
\text { Gerakan, Ekspresi }\end{array}$ & Naratif \\
\hline 2 & Level Representasi & $\begin{array}{l}\text { Kamera, Pencahayaan, } \\
\text { Penyuntingan, Musik, }\end{array}$ & Sinematografi \\
\hline 3 & Level Ideologi & $\begin{array}{l}\text { Individualisme, Patriarki, Ras, Kelas, } \\
\text { Materialisme, Kapitalisme }\end{array}$ & Naratif \\
\hline
\end{tabular}

Penulis mencoba menemukan lingkungan sosial yang baik melalui Film Chef dengan pendekatan semiotika film yang digunakan dalam penelitian ini adalah semiotika John Fiske yang memiliki 3 tahapan analisis (Hasanah \& Taefur, 2016; Vera, 2014), seperti pada tabel 1 diatas.

\section{METODE PENELITIAN}

Paradigma penelitian dibutuhkan agar penulis memiliki pijakan filosofis dalam menentukan arah penelitiannya apakah berada pada arah positivisme, postpositivisme, konsturktivisme, transformatif, dan pragmatisme (Creswell, 2007) dimana masingmasing paradigma mampu menjadi landasan filosofis penulis dalam usaha menemukan kebenaran melalui aktifitas penelitiannya. Penelitian ini menggunakan paradigma konstruktivisme sosial yang menurut Denzin paradigma ini sering dikombinasikan dengan interpretivisme dimana pandangan-pandangan intepretif berpijak pada asumsi bahwa gambaran realitas sosial kaum empiris menghilangkan sesuatu yang sangat penting yaitu makna-makna umum, intersubjektif, serta cara-cara mewujudkan tindakan dalam masyarakat yang diekspresikan dalam bahasa dan deskripsi-deskripsi yang membentuk institusi dan praktik (Denzin \& Lincoln, 2009). 
Metode yang digunakan dalam penelitian ini adalah kualitatif deskriptif dengan pendekatan semiotika pada cabang semiotika pragmatis dimana metode ini digunakan untuk mempelajari aspek-aspek komunikasi yang memiliki fungsi situasional yang melatari tuturan yang berhubungan dengan tanda yang dintepretasikan (Indiwan Seto Wahyu Wibowo, 2006; LittleJohn \& Foss, 2009; Setiawan, 2019). Aspek komunikasi yang dipelajari dalam penelitian ini adalah interaksi tokoh dalam film Chef sehingga subjek penelitiannya adalah interaksi Carl Casper (Ayah) dengan Percy (Anak) dan audiovisual film yang memiliki 2 unsur yaitu naratif dan sinematografi akan menjadi objek penelitian ini yang akan digali dengan mengungkap realitas film yang ada pada interaksi Casper dan Percy dalam Film Chef dengan menggunakan Semiotika John Fiske.

\section{HASIL DAN PEMBAHASAN}

Langkah awal penulis adalah mengumpulkan data interkasi karakter Carl dan Percy pada Film berdurasi 110 menit ini dimana film ini menghadirkan interaksi sosial, hiruk pikuk pekerjaan, tekanan dalam pekerjaan, wilayah privasi manusia, hingga ambisi dan luapan amarah yang seutuhnya diramu dalam interaksi karakter dengan media sosial (twitter). Interaksi yang dimaksud dalam penelitian ini adalah interaksi Ayah dan Anak dimana Carl adalah karakter seorang chef pekerja keras, mencintai pekerjaannya dan sering melakukan improvisasi serta berkreasi dengan masakan yang ia masak. Disisi lain Carl adalah seorang ayah yang buruk bagi Percy, anak tunggalnya hasil pernikahannya dengan Inez seorang wanita sexy representasi wanita karir di kota besar.

Penulis mengumpulkan dan menganalisa serta terhadap 38 adegan interaksi Carl dan Percy selama film dan mengelompokkan adegan interaksi Carl dan Percy merujuk pada unsur audiovisualnya yaitu naratif dan sinematografi (Vera, 2014).

Tabel 2. Adegan Interaksi Carl dan Percy di Mobil [Sumber : Olahan Data Penulis]

\begin{tabular}{|l|l|l|l|l|}
\hline \multirow{2}{*}{ Visual } & \multicolumn{2}{|c|}{ Scene /Adegan } & \multicolumn{2}{c|}{ Unsur Audiovisual (Vera, 2014) } \\
\cline { 2 - 5 } & Penuturan & \multicolumn{1}{c|}{ Lokasi } & \multicolumn{1}{c|}{ Naratif } & \multicolumn{1}{c|}{ Sinematik } \\
\hline & $\begin{array}{l}\text { Carl } \\
\text { terlambat } \\
\text { menjemput } \\
\text { Percy }\end{array}$ & Ext. Mobil & Dialog Carl dan & Eye Level, \\
Carl & $\begin{array}{l}\text { Percy yang } \\
\text { One Shot } \\
\text { menyarankan } \\
\text { kepada } \\
\text { ayahnya untuk } \\
\text { memulai bisnis } \\
\text { food truck, } \\
\text { namun tidak } \\
\text { ditanggapi } \\
\text { Carl. }\end{array}$ \\
\hline
\end{tabular}

Awal penuturan ceritanya Carl dan Inez, ibu Percy sepakat tetap menjalin komunikasi yang baik demi bersama membesarkan dan merawat serta mendidik Percy. Setiap pukul 10 pagi di akhir pekan, Carl harus menjemput Percy untuk tinggal bersama Carl di apartemennya namun di awal penuturuan cerita Carl selalu terlambat dan tidak menempatkan Percy pada prioritasnya di akhir pekan karena Carl mendapat tekanan dari pekerjaannya. 
Interaksi karakter Carl dan Percy pada babak awal film digambarkan tidak terlalu dekat dimana Percy selalu duduk di bangku belakang mobil Carl, dialog Carl dan Percy dimediasi oleh kaca spion mobil Carl dan Percy mencoba memberikan saran kapada Carl untuk memulai bisnis food truck namun Carl menanggapinya dingin serta selama di apartemen Carl tidak ada interaksi antara Carl dan Percy.

Tabel 3. Adegan Interaksi Carl dan Percy di Pasar [Sumber : Olahan Data Penulis]

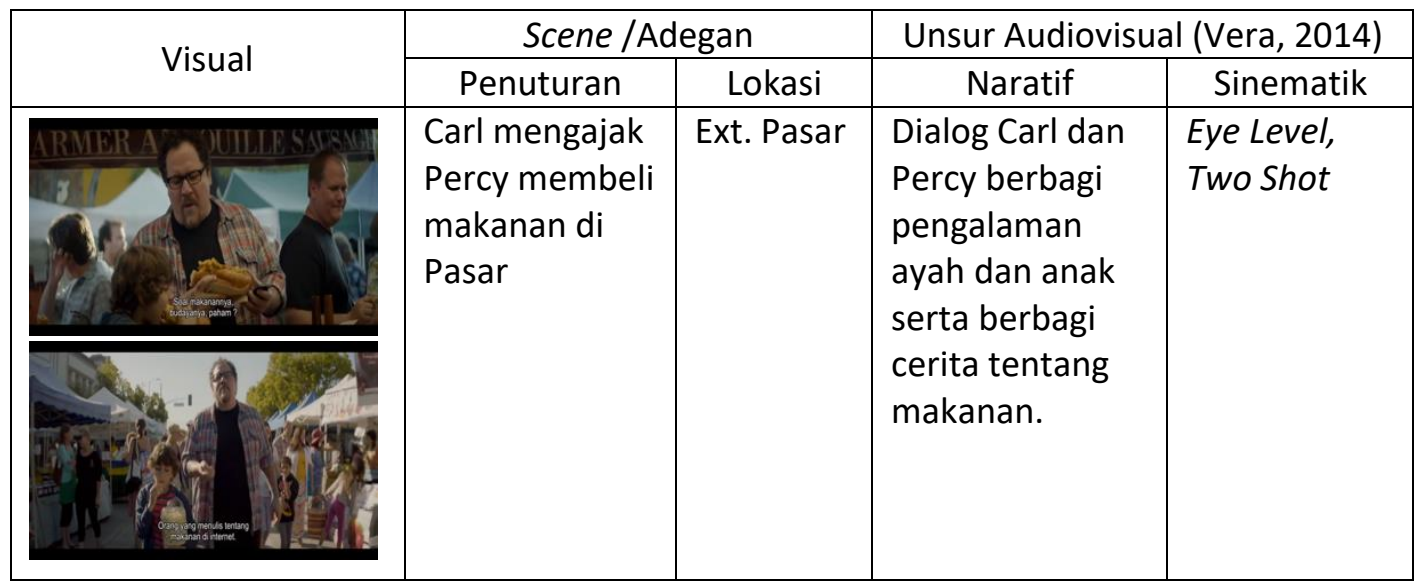

Interaksi Carl dan Percy mulai terbangun dan tanpa jarak pada saat kedua karakter tersebut melakukan aktivitas bersama di sebuah pasar dan Carl menceritakan ada sebuah makanan enak yang bernama Beignet dan ia berjanji akan mengajak Percy ke New Oerlans untuk mencicipi makanan tersebut langsung dari tempat dimana makanan itu dimasak. Interkasi Carl dan Percy kembali memburuk pada saat Carl meminta Percy untuk medaftarkan dirinya pada akun Twitter dan Carl mulai depresi kembali dengan aktifitas netizen pada akunnya tersebut dimana kritik negatif seorang kritikus masakan membuat Carl tidak dapat mengontrol emosinya dan bergegas meluapkan emosinya segera setelah ia dipecat dari restoran tempat ia bekerja dan video tersebut viral. Dengan peliknya masalah pekerjaan yang dihadapinya, Carl membatalkan janjinya kepada Percy untuk membawanya ke New Oerlans dan Percy sangat kecewa. Sebuah penyesalan yang dirasakan Carl yang akhirnya Inez mengajak Carl dan Percy untuk ikut dalam perjalanan bisnisnya ke Miami dan Carl sepakat membuat perjanjian dengan Inez untuk mengajak Percy terlibat dalam merintis Food Truck yang akan dimulainya.

Interkasi utama Carl dan Percy dimulai dari awal kedua karakter tersebut bekerja sama untuk membersihkan food truck yang mereka dapatkan dari mantan suami ke dua Inez. Interkasi Ayah dan Anak berubah ketika Carl memberikan instruksi tegas kepada Percy untuk membersihkan wadah makanan busuk. Percy marah dan pergi meninggalkan Carl. Karakter ayah dan anak itupun bersepakat bekerja sama selayaknya tim masak di dapur dan pertolongan pun datang dari Martin sahabat setia Carl yang bersedia datang dan membantu mereka merintis food truck "El Jefe" dan mereka bertiga memulai perjalanannya ke kota-kota besar di Amerika hingga akhirnya Carl dan Percy membuat kesepakatan di kota terakhir yaitu Texas untuk tetap melanjutkan bisnis Food Truck ini pada setiap akhir pekan dan Percy ikut sebagai juru masaknya serta seluruh gaji Percy ditabung untuk biaya kuliahnya. 
Tabel 4. Adegan Interaksi Carl dan Percy di "El Jefe"

[Sumber : Olahan Data Penulis]

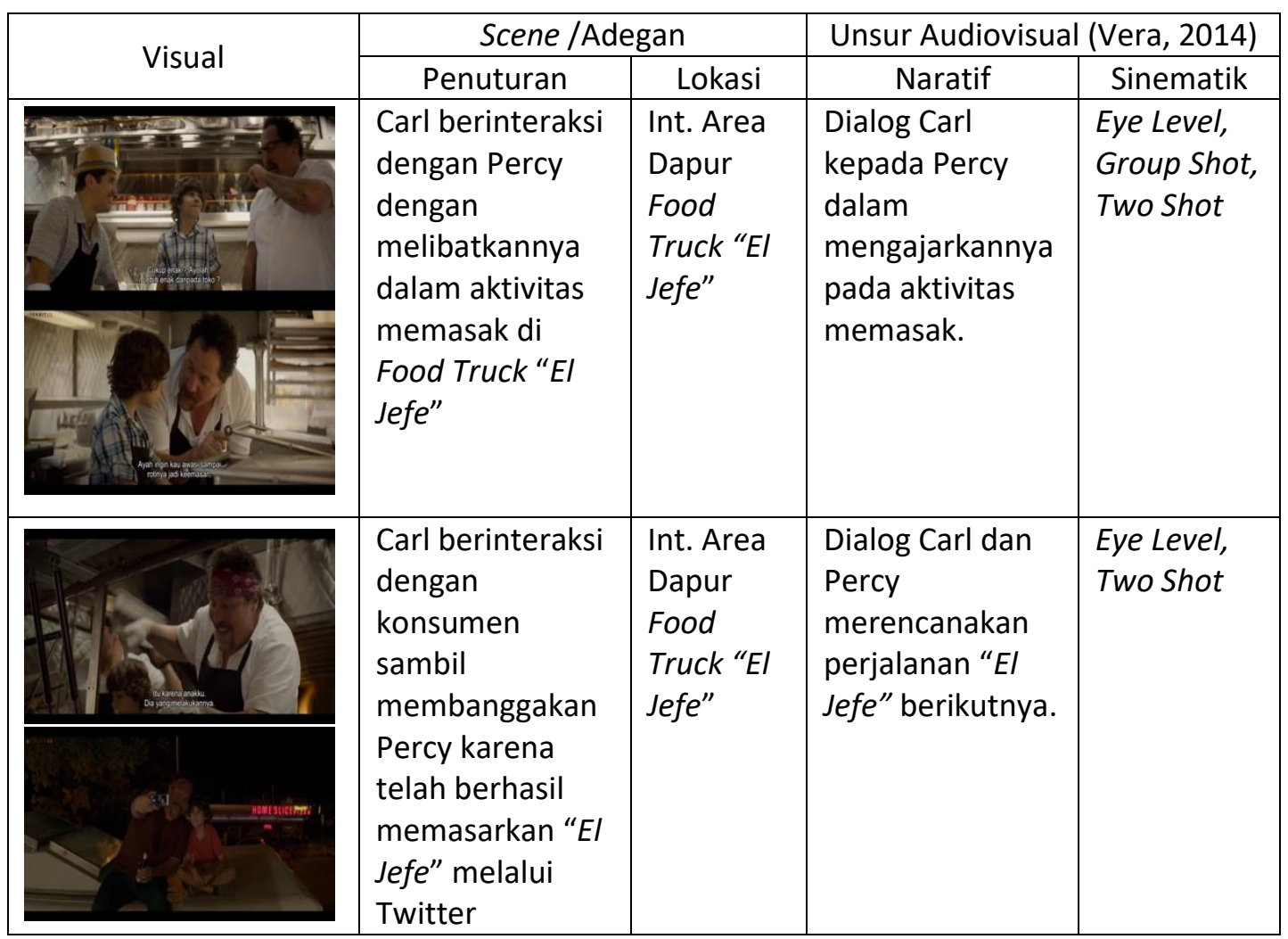

Beberapa gambar diatas menghadirkan visualisasi interaksi karakter Carl dan Percy selama scene memasak, berjualan, dan mencicipi makanan yang akan mereka jual di food truck "El Jefe" terlihat jelas dan tanpa batas. Penulis menemukan banyak sekali ruang-ruang sempit yang diciptakan dalam film ini untuk menggambarkan keintiman dan interkasi karakter Ayah dan Anak tersebut. Secara senimatografi pemilihan media food truck untuk menggambarkan interkasi ayah dan anak sangat tepat karena ruangruang sempit pada area dapur di food truck tersebut menjadi media visual yang baik menggambarkan realitas visual interkasi ayah dan anak mampu menjadi media yang baik bagi tumbuh kembang anak tersebut.

Semiotika John Fiske secara lugas dapat mengarsir batasan level realitas dalam penelitian ini. Level realitas, representasi, dan ideologi pada interaksi karakter Carl dan Percy pada film Chef dipisahkan dengan tegas pada film ini seperti lokasi yaitu food truck "El Jefe" memberikan gambaran yang jelas bahwa ruang-ruang sempit dalam food truck tersebut terus membaik dan semakin intim. Ekspresi wajah karakter, narasi/dialog yang muncul dan bagaimana Carl memperlakukan Percy dalam 2 bentuk yaitu anak dan mitra kerjanya di "El Jefe" menjadi bentuk lain dari level realitas yang divisualkan dalam film ini.

Level Realitas yang diciptakan dalam memberikan gambaran interaksi karakter Carl dan Percy melalui lingkungan dalam frame dan scene yang diciptakan padat dan sempit dengan objek dominan adalah Karakter Carl dan Percy. 
Tabel 5. Level Realitas

[Sumber : Olahan Data Penulis]

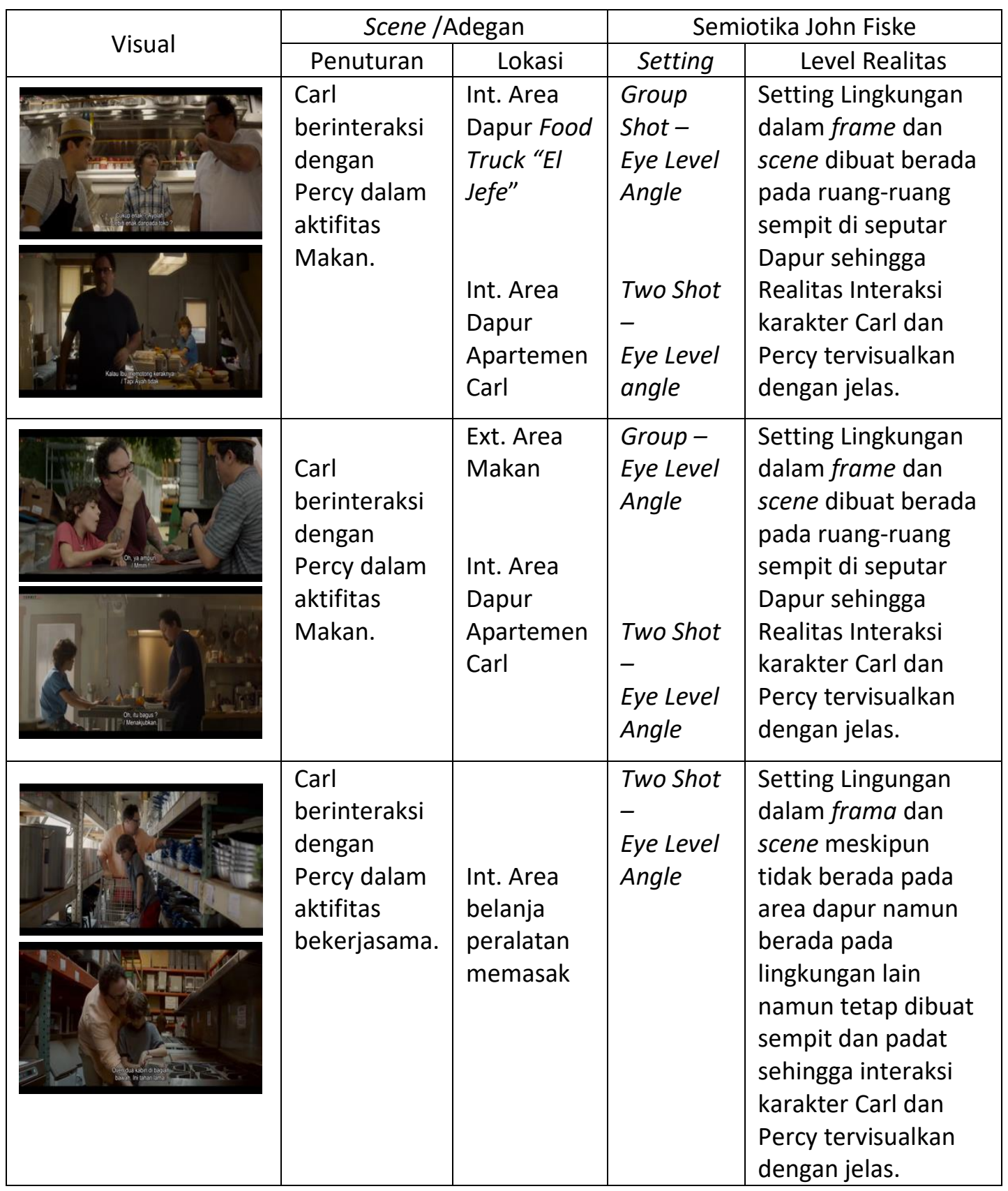

Level realitas pada tabel diatas diciptakan dalam gambaran lingkungan sempit dan padat pada frame dan scene dalam film sehingga interaksi antar karakter Carl (ayah) dan Percy (anak) menjadi fokus dalam sensasi visualnya. Narasi-narasi yang hadir dalam kalimat verbal maupun nonverbal pada kedua karakter tersebut memberikan gambaran bahwa interaksinya berjalan dalam beberapa kondisi. Selanjutnya level representasi menjadi penunjang level realitas dalam film dimana sudut pengambilan gambar (angle) yang ditentukan pada realitas visual dalam film ini. Level representasi dihadirkan melalui batasan-batasan tegas dalam penentuan sudut pengambilan gambar (angle) yang memberikan makna tegas posisi Carl dan Percy dalam cerita. Kondisi cerita yang 
dihadirkan melalui sudut pengambilan gambar (angle) memberikan sensasi visual bagi penonton dalam mengikuti interaksi karakter Carl dan Percy dalam film tersebut.

Tabel 6. Level Representasi

[Sumber : Olahan Data Penulis]

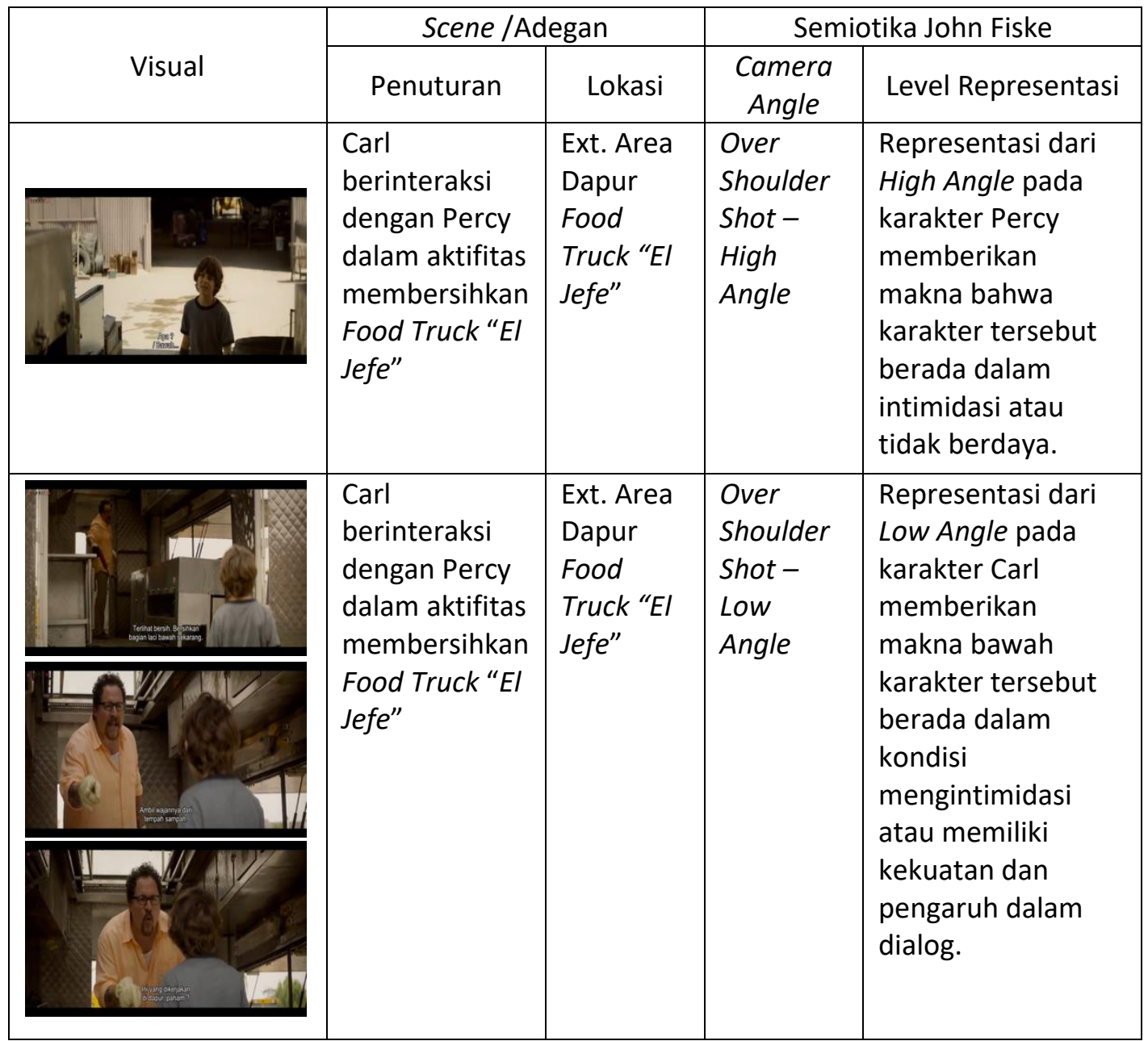

Sudut pengambilan gambar (angle) dalam adegan interaksi Carl dan Percy diatas meskipun cenderung monoton namun mampu memberikan batasan jelas posisi yang memiliki kuasa (Carl) yang diwakilkan dengan sudut pengambilan gambar low angle yang bermakna bahwa sudut pengambilan gambar ini memberikan makna visual objek tersebut berkuasa dan memiliki kekuatan untuk mengintimidasi objek karakter Percy yang diwakilkan dengan sudut pengambilan gambari high angle yang bermakna sebaliknya dari low angle. Berikutnya eye level angle yang menjadi sudut pengambilan gambar yang lazim digunakan dalam penyampaian level representasi pada film ini menjadi medium naratif bagi level realitas interaksi karakter Carl dan Percy.

Level representasi lain yang dihadirkan dalam interaksi karakter Carl dan Percy mayoritas dengan pengambilan gambar over shoulder shot dan komposisi two atau group shot sehingga penonton dapat secara langsung terlibat dalam interaksi karakterkarakter dalam film ini. Selanjutnya, level ideologi dalam Film Chef didominasi oleh ideologi patriarki dimana karakter Carl yang sangat mencintai pekerjaannya melibatkan 
karakter Percy yang adalah anaknya. Seluruh interaksi karakter Carl dan Percy yang terjadi dalam film ini adalah interaksi ayah dan anak atau chef kepada timnya sehingga Carl lebih cenderung mendominasi interkasi. Namun hal unik yang terjadi dalam film ini dimana karakter Percy tidak serta-merta tinggal diam dan tetap memberikan masukan kepada ayahnya namun tetap menjadi tim yang baik untuk mendukung promosi food truck mereka melalui twitter serta membantu chef bekerja di "El Jefe."

Ideologi patriaki yang dihadirkan dalam bentuk interaksi karakter Carl dan Percy dapat menjadi representasi realitas orang tua (ayah / ibu) yang bercerai dalam melakukan aktifitas komunikasi dengan anaknya sebagai korban dari berceraian mereka tersebut. Film ini banyak memberikan realitas interaksi ayah dan anak itu dapat membantu anak memahami kondisi ayahnya dan melibatkan anak dalam beberapa aktivitas ayahnya demi membentuk interaksi antar keduanya.

\section{KESIMPULAN}

Film ini dapat dijadikan referensi membangun interaksi ayah dan anak karena hasil dari temuan data film yang dianlisis dengan pendekatan semiotika John Fiske level realitas, representasi, dan ideologi yang dihadirkan menggambarkan realitas keluarga interaksi ayah dan anak. Penuturan /adegan dalam film ini diciptakan pada fokus interkasi Carl (ayah) dan Percy (anak) dalam membangun hubungannya pasca bercerai. Dalam aspek pendekatan semiotika John Fiske pada level realitas dibangun dengan setting lingkungan lokasi food truck dan lokasi lain mampu memberikan sensasi visual yang fokus dan padat ditambah dengan narasi melalui dialog antar karakter tersebut.

Gambaran ruang-ruang sempit di dalam area food truck maupun area lain membuat interaksi karakter Carl dan Percy semakin intim terjadi. Level representasi pada film ini tervisualkan dengan baik pada pemilihan sudut pangambilan gambar (angle) dan komposisi gambar merepresentasikan interaksi Carl (ayah) dan Percy (anak). Level Ideologi yang dihadirkan dalam film adalah patriarki yang memberikan gambaran bahwa membangun interaksi ayah dan anak tidaklah mudah namun bukan tidak mungkin untuk dilakukan. Interaksi ayah dan anak perlu terus dilakukan agar anak tidak kehilangan sosok orang tuanya dan film ini menggambarkan realitas yang baik untuk ideologi patriarki tersebut.

\section{DAFTAR PUSTAKA}

Creswell, J. W. (2007). Qualitative Inquiry And Research Design: Choosing Among Five Traditions. Sage Publications.

Denzin, N. K., \& Lincoln, Y. S. (2009). Handbook Of Qualitative Research. Sage Publication, Inc.

Dezheng, F. (2012). Modeling Appraisal In Film: A Social Semiotic Approach Feng Dezheng. Shandong University.

Erica, R. H. (2010). Film As Identity Exploration: A Multimodal Analysis Of YouthProduced Films. Teachers College Record, 112(9), 2352-2378.

Fahrian. (2017). Representasi Komunikasi Interaktif Budaya Barat Pada Film "Chef" Karya John. Ejurnal Ilmu Komunikasi, 5961(3), 248-262. 
Fiske, J. (1985). The Semiotics Of Television. Critical Studies In Mass Communication, 2(2), 176-183.

Hasanah, R., \& Taefur, I. (2016). The Shift Meaning Of Masculinity In Nivea Deodorant Men Invisible Black And White Advertising (Television Code By John Fiske). In International Conference On Transformation In Communication (ICOTIC).

Heller, M. A. (1982). Semiology: A Context For Television Criticism. Journal of Broadcasting, 26(4), 847-854.

Holmes, D. (2005). Communication Theory Media, Technology And Society. Sage Publication, Inc.

Indiwan Seto Wahyu Wibowo. (2006). Semiotika Aplikasi Praktis Bagi Penelitian Dan Penulisan Skripsi IImu Komunikasi. Jakarta: Fakultas IImu Komunikasi Universitas Prof. Dr. Moestopo (Beragama).

Littlejhon, S. W., \& Foss, K. A. (2009). Teori Komunikasi Edisi 9 (Terjemahan). Jakarta: Salemba Humanika.

Littlejhon, S. W., \& Foss, K. A. (2016). Ensiklopedia Teori Komunikasi (Terjemahan). Jakarta: Kencana.

Mulyana, D. (2017). Ilmu Komunikasi Suatu Pengantar (Edisi Revisi) (Revisi). Bandung: Remaja Rosdakarya.

Mulyana, D. (2018). Metodologi Penelitian Kualitatif (Edisi Revisi). Bandung: Remaja Rosdakarya.

Nico, R. (2016). Analisa Semiotika Penggunaan Twitter Pada Film Chef (Studi Semiotika Charles Sanders Peirce Tentang Metode Buzz Marketing Dengan Menggunakan Twitter Dalam Film Chef). Universitas Telkom.

Nurul, A., \& Nugroho, C. (2017). Representasi Pemikiran Marxisme Dalam Film Biografistudi Semiotika John Fiske Mengenai Pertentangan Kelas Sosial Karl Marx Pada Film Guru Bangsa Tjokroaminoto. Semiotika: Jurnal Komunikasi, 11(1), 1-33.

Setiawan, H. (2016). Aplikasi Semiotik Dalam Iklan Di " Dunia Nyata" ( Peningkatan Brand Awareness Dibalik Iklan Yang Membingungkan ) (Pp. 1-16). Retrieved From Https://Www.Researchgate.Net/Profile/Harry_Setiawan/Publication/ 326734328_Aplikasi_Semiotikdalam_Iklan_Di_Dunia_Nyata_Peningkatan_Bra nd_Awareness_Dibalik_Iklan_Yang_Membingungkan/Links/5ba5d0e5299bf13 e60436a1c/Aplikasi-Semiotikdalam-Iklan-Di-Dunia-Nyata-P

Setiawan, H. (2019). Memiilih Diantara 7 Tradisi Ilmu Komunikasi Dalam Kerangka Filosofis. Jurnal Darussalam: Jurnal Pendidikan, Komunikasi Dan Pemikiran Hukum Islam, 11(1), 18.

Sobur, A. (2003). Semiotika Komunikasi. Bandung: Remaja Rosdakarya.

Spradley, J. P. (2007). Metode Etnografi. Yogyakarta: Tiara Wacana.

Suriasumantri, J. S. (2017). Filsafat Ilmu Sebuah Pengantar Populer. Jakarta: Pustaka Sinar Harapan.

Tseng, C. I. (2013). Analysing Characters' Interactions In Filmic Text: A Functional Semiotic Approach. Social Semiotics, 23(5), 587-605.

Vera, N. (2014). Semiotika Dalam Riset Komunikasi. Bogor: Ghalia Indonesia.

Wulandari P.W, M. (2016). Representasi Peran New Media Dalam Membangun Reputasi Pada Film Chef (Analisis Semiotika John Fiske). Universitas Islam Sultan Agung. 